\title{
Qualitative and Quantitative Assessment of Petroleum Contaminants in Soils under Tropical Weather Conditions
}

\author{
Imeh Okop, Krishna Persaud \\ School of Chemical Engineering and Analytical Science, The University of Manchester, Manchester, UK \\ Email: imehokop@aksu.edu.ng
}

How to cite this paper: Okop, I. and Persaud, K. (2019) Qualitative and Quantitative Assessment of Petroleum Contaminants in Soils under Tropical Weather Conditions. American Journal of Analytical Chemistry, 10, 112-125.

https://doi.org/10.4236/ajac.2019.103010

Received: May 31, 2018

Accepted: March 25, 2019

Published: March 28, 2019

Copyright ( 2019 by author(s) and Scientific Research Publishing Inc. This work is licensed under the Creative Commons Attribution International License (CC BY 4.0).

http://creativecommons.org/licenses/by/4.0/

\section{Open Access}

\begin{abstract}
GC-FID methods for the analysis of Petroleum hydrocarbons were developed and optimised. Contamination of soil from the Niger Delta was investigated about 40 days after crude oil spillage from the Shell Petroleum marginal well head. Soil samples and controls were collected at depths of $0-15 \mathrm{~cm}, 15-30$ $\mathrm{cm}$ and $30-60 \mathrm{~cm}$. Samples were analysed using gas chromatography fitted with a flame ionisation detector. Penetration and migration of $\mathrm{C}_{10}-\mathrm{C}_{26}$ and $\mathrm{C}_{26}-\mathrm{C}_{34}$ hydrocarbons through the soil layers were assessed by cluster analysis to determine the spatial distribution, penetration and similarity of these compounds over the contaminated area. The results also indicated elevated levels of total hydrocarbon contents when compared with the reference sites. Recommendations are made to carefully monitor and remediate the environment.
\end{abstract}

\section{Keywords}

Oil Spill, Petroleum Contaminated Soils, Total Petroleum Hydrocarbon, Gas Chromatography-Flame Ionisation Detector (GC-FID) Analysis

\section{Introduction}

Environmental pollution due to the increasing release of hazardous and toxic substances into the soil, water, sediment and air in Niger Delta, Nigeria has been a widespread problem in recent years. Indeed soil contamination by oil exploration activities has quickly become a considerable environmental issue [1] [2] [3]. It is obvious that petroleum contamination of soils and water has become a topic of interest and is attracting increasing attention because of the carcinogenic, mutagenic and toxic effects. [4] [5] [6]. The aim of this work was to study, de- 
velop and implement validated and traceable methodology for qualitative and quantitative assessment of petroleum contaminants in soils of Niger Delta under tropical weather conditions. The method involved the use of a Gas Chromatograph (GC) fitted with flame ionisation detector capable of split injection with a Varian CP-Sil-GC capillary column and Combi Pal. Optimum extraction time for the soil samples was established using dichloromethane (DCM) by comparing the extraction efficiencies of other solvents.

Gas chromatography is one of the most powerful, popular, unique and readily versatile analytical techniques used for the separation, identification, and quantitative assay of compounds in the vapour state. It still remains the most important single technique for oil spill identification partly because the equipment is relatively available, and easy to operate with small amount of operator time and considerable amount of information can be gathered on using a high resolution (capillary) column. This study sought to establish the concentration of the contaminants, and apply cluster observation analysis to characterize chemically similar hydrocarbons over the contaminated area. This analytical information would be usefully employed in each petroleum spill site to access the level of contamination and to efficiently and safely remove the spilled petroleum products from the soil with the aim of returning the soil back to a useable form. Attempts for complete removal may not be practically more attainable than to remediate the soils to the concentration levels that will be harmless to plants, fauna, human health and the entire ecosystem [7] [8]. The way to handle, dispose or reuse non-hazardous petroleum contaminated soils has received attention [9].

\section{Experimental}

\subsection{Sampling}

Sampling is considered a vital and one of the most crucial steps in the procedure of analysis of organic contaminants in soils and sediments of our environment [10] [11]. A sampling site was located in Ikot Ada Udo, Ikot Abasi in Akwa Ibom State, South-South Niger Delta, Nigeria. At this site, soil and water have been repeatedly subjected to petroleum spillages and crude oil leakages from a Shell marginal oil pipeline. An initial site investigation survey [12] was carried out on the site prior to sampling. Forty seven (47) samples were taken from the site at three points around the well head (Table 1).

Table 2 shows the location number, sample number, distance from the well head and direction coordinates of samples.

\subsection{Sample Collection}

Auger boring often provides the simplest method [13] for soil investigation. A hand soil auger (Nickel-plated carbon steel, 3" diameter) was used to collect soil samples from the site by taking about 6 - 10 auger borings at random grid at sampling points to depths of $0-15 \mathrm{~cm}$ at the top soil, $15-30 \mathrm{~cm}$ at mid 
Table 1. Total number of samples and depth of sampling.

\begin{tabular}{|c|c|c|c|}
\hline Sample location & Sample identity & Sample depth each $(\mathrm{cm})$ & Total number of samples \\
\hline & & $0-15$ & \\
\hline \multirow[t]{3}{*}{ A } & A1 to $\mathrm{A} 10$ & $15-30$ & 30 \\
\hline & & $30-60$ & \\
\hline & & $0-15$ & \\
\hline \multirow[t]{3}{*}{ B } & A11 to $\mathrm{A} 14$ & $15-30$ & 12 \\
\hline & & $30-60$ & \\
\hline & & $0-15$ & \\
\hline \multirow[t]{3}{*}{$\mathrm{C}$} & A 15 to $\mathrm{A} 17$ & $15-30$ & 5 \\
\hline & & $30-60$ & \\
\hline & & & 7 \\
\hline
\end{tabular}

Table 2. Sample description table.

\begin{tabular}{|c|c|c|c|c|c|}
\hline Hole & $\begin{array}{l}\text { Sample } \\
\text { ID }\end{array}$ & Description & $\begin{array}{l}\text { No. of } \\
\text { Samples }\end{array}$ & $\begin{array}{l}\text { Depth } \\
(\mathrm{cm})\end{array}$ & $\begin{array}{c}\text { Position coordinates } \\
\text { north east }\end{array}$ \\
\hline 1 & $\mathrm{~A} 1$ & $\begin{array}{l}5 \text { meters }(\mathrm{m}) \text { from } \\
\text { the Well head-the } \\
\text { Reference Point (RP) }\end{array}$ & 3 & $\begin{array}{c}0-15 \\
15-30 \\
30-60\end{array}$ & $4^{\circ} 41^{\prime} 49.4^{\prime \prime} \& 7^{\circ} 41^{\prime} 09.8^{\prime \prime}$ \\
\hline 2 & $\mathrm{~A} 2$ & $\begin{array}{c}10 \mathrm{~m} \text { from } \\
\text { Well head RP }\end{array}$ & 3 & $\begin{array}{c}0-15 \\
15-30 \\
30-60\end{array}$ & $4^{\circ} 41^{\prime} 50.5^{\prime \prime} \& 7^{\circ} 41^{\prime} 09.12^{\prime \prime}$ \\
\hline 3 & A3 & $\begin{array}{c}20 \mathrm{~m} \text { from } \\
\text { Well head RP }\end{array}$ & 3 & $\begin{array}{c}0-15 \\
15-30 \\
30-60\end{array}$ & $4^{\circ} 41^{\prime} 49.3^{\prime \prime} \& 7^{\circ} 41^{\prime} 11.4^{\prime \prime}$ \\
\hline 4 & A4 & $50 \mathrm{~m}$ from $\mathrm{RP}$ & 3 & $\begin{array}{c}0-15 \\
15-30 \\
30-60\end{array}$ & $4^{\circ} 41^{\prime} 48.6^{\prime \prime} \& 7^{\circ} 41^{\prime} 10.1^{\prime \prime}$ \\
\hline 5 & A5 & $100 \mathrm{~m}$ from $\mathrm{RP}$ & 3 & $\begin{array}{c}0-15 \\
15-30 \\
30-60\end{array}$ & $4^{\circ} 41^{\prime} 47.2^{\prime \prime} \& 7^{\circ} 41^{\prime} 09.9^{\prime \prime}$ \\
\hline 6 & A6 & $150 \mathrm{~m}$ from $\mathrm{RP}$ & 3 & $\begin{array}{c}0-15 \\
15-30 \\
30-60\end{array}$ & $4^{\circ} 41^{\prime} 48.8^{\prime \prime} \& 7^{\circ} 41^{\prime} 09.1^{\prime \prime}$ \\
\hline 7 & A7 & $100 \mathrm{~m}$ from $\mathrm{RP}$ & 3 & $\begin{array}{c}0-15 \\
15-30 \\
30-60\end{array}$ & $4^{\circ} 41^{\prime} 49.7^{\prime \prime} \& 7^{\circ} 41^{\prime} 09.3^{\prime \prime}$ \\
\hline 8 & A8 & $150 \mathrm{~m}$ from $\mathrm{RP}$ & 3 & $\begin{array}{c}0-15 \\
15-30 \\
30-60\end{array}$ & $4^{\circ} 41^{\prime} 47.7^{\prime \prime} \& 7^{\circ} 41^{\prime} 07.6^{\prime \prime}$ \\
\hline 9 & A9 & $10 \mathrm{~m}$ from $\mathrm{RP}$ & 3 & $\begin{array}{c}0-15 \\
15-30 \\
30-60\end{array}$ & $4^{\circ} 41^{\prime} 50.3^{\prime \prime} \& 7^{\circ} 41^{\prime} 10.6^{\prime \prime}$ \\
\hline 10 & A10 & $\begin{array}{c}\text { Well Head, } \\
\text { (WH)-(Spillage and } \\
\text { Reference Point. RP) }\end{array}$ & 3 & $\begin{array}{c}0-15 \\
15-30 \\
30-60\end{array}$ & $4^{\circ} 41^{\prime} 49.8^{\prime \prime} \& 7^{\circ} 41^{\prime} 10.4^{\prime \prime}$ \\
\hline 11 & A11 & $50 \mathrm{~m}$ from $\mathrm{RP}$ & 3 & $\begin{array}{c}0-15 \\
15-30 \\
30-60\end{array}$ & $4^{\circ} 41^{\prime} 48.4^{\prime \prime} \& 7^{\circ} 41^{\prime} 09.7^{\prime \prime}$ \\
\hline
\end{tabular}




\begin{tabular}{|c|c|c|c|c|c|}
\hline \multicolumn{6}{|c|}{ Continued } \\
\hline \multirow{3}{*}{12} & \multirow{3}{*}{ A12 } & \multirow{3}{*}{$150 \mathrm{~m}$ from $\mathrm{RP}$} & \multicolumn{2}{|r|}{$0-15$} & \multirow{3}{*}{$4^{\circ} 41^{\prime} 49^{\prime \prime} \& 7^{\circ} 41^{\prime} 09.5^{\prime \prime}$} \\
\hline & & & 3 & $15-30$ & \\
\hline & & & & $30-60$ & \\
\hline 13 & $\mathrm{~A} 13$ & NA & 3 & Same as above & - \\
\hline 14 & A14 & NA & 3 & Same as above & - \\
\hline 15 & $\mathrm{~A} 15$ & NA & 3 & Same as above & - \\
\hline $16-17$ & A16 A17 & NA & 3 & Same as above & - \\
\hline
\end{tabular}

(sub-surface) and bottom layer of 30 to $60 \mathrm{~cm}$. The auger was cleaned with deionised water and rinsed with methanol after each sampling point. Three sub-samples were collected at each sampling point of the designated depths. Representative soil samples from the auger were taken into fresh polythene bags with seal and further placed in a pre-cleaned glass bottle with a clean Teflon-lined lid. Approximately $500 \mathrm{~g}$ of soil was collected at each sample depth. Four control site samples (duplicate sample blanks) were taken from the same geographically uncontaminated soil to determine the background levels of petroleum hydrocarbons for comparison with the contaminated soil.

\subsection{Preservation and Transportation}

The entire sampling exercise was carried out in one day. The average ambient temperature was $28^{\circ} \mathrm{C}$. All the samples were placed in icebox and transported to the laboratory. Storage was done at $4^{\circ} \mathrm{C}$ until analysis was completed in two weeks.

\subsection{Sample Preparation, Extraction and Clean-Up}

Extraction of petroleum contaminants from the soil took place prior to analytical determination. Soxhlet extraction with modified Brinkmann Büchi automated apparatus was used. Soxhlet extraction is a U. S. EPA [14] and ASTM [15] approved method for semivolatile and non-volatile organic contaminants from solid materials such as soil. All samples were extracted using the Soxhlet extraction procedures as outlined in U.S. EPA method 3540 [14] and ASTM method D5369 [15] with slight modifications in the solvent choice and volume, extraction time and size of extraction flasks.

This procedure involves extraction of the petroleum contaminants from about $10 \mathrm{~g}$ weight of dry oil-spilled soil with a suitable solvent. Soxhlet extraction really ensures intimate contact of the sample matrix with the extraction solvent and a reasonably large amount of $3-20 \mathrm{~g}$ could be used to allow quantitative extraction. The Soxhlet technique is the usually adopted reference method. It has been proposed by many agencies [16] [17] as a method of choice for extraction of non-polar organic contaminants.

The choice of this extraction method amidst other recent extraction techniques includes its peculiar application, availability in the laboratory and the 
ease of setting up with minimal or no cost. Its drawbacks include delayed extraction period and use of appreciable volume of solvent. Other methods of extraction may not be labour intensive but due to their cost may not be accessible to every laboratory.

Optimum extraction time of about 2.5 hours was established using dichloromethane (DCM) after comparing with other solvents such as methanol, hexane, acetone, toluene and ethyl benzene. DCM proved to be the most suitable solvent over hexane, acetone, toluene and ethyl benzene for this extraction due to its consistency, efficiency and ability of not interfering with BTEX retention time window $(\mathrm{RTW})-\mathrm{C}_{5}-\mathrm{C}_{9}$. This was indicative that Tropical soil in south-south Niger.

Delta favoured efficient extraction with DCM as solvent.

\section{Materials and Methods}

In this work, dichloromethane (99.8\%) used as the extracting solvent was supplied by Sigma Aldrich. Reference standards used were BTEX (benzene, toluene, ethylbenzene and xylene) Mix, catalog No. 47993 supplied by Supelco analytical, Bellefonte, PA, USA; Kit for the chromatographic determination of hydrocarbon content in soil according to DIN ISO 16703 and in waste according to EN 14039 comprising of the following: Standard solution for the determination of the retention time window (RTW), cat. No. 67583; Mineral Oil standard mixture type A and B for DIN EN 14039 and ISO 16703 (cat. No. 69246); Alkane standard mixture (cat. No. 68281) for the assay of the system efficiency of GC's $\left(\mathrm{C}_{10}-\mathrm{C}_{40}\right)$; Heptane, Puriss. p.a (cat. No. 51745) and Dual layer Florisil $/ / \mathrm{Na}_{2} \mathrm{SO}_{4} \mathrm{SPE}$ Tube, 2 g/2 g/6 mL (Cat. No 40080-1ea-F) all supplied by Fluka Analytical, Sigma Aldrich.

Diesel Range Organics (DRO) Mix (Tennessee/Mississippi), catalog No. 31214, Lot No. AO62141 was supplied by Restek, PA, USA. Hydrocarbon internal standards $\mathrm{C}_{14}, \mathrm{C}_{15}$, verification standards $\left(\mathrm{C}_{10}, \mathrm{C}_{11}, \mathrm{C}_{14}, \mathrm{C}_{15}\right.$ and TCD) prepared in the laboratory were all HPLC and of analytical reference grades.

\subsection{Sample Collection, Preservation and Extraction}

About $500 \mathrm{~g}$ of labelled petroleum contaminated soil samples were collected into zipped plastic bags and put into a glass jar sealed with Teflon lined cap. Nickel plated carbon steel hand auger was used in scooping the soil at three different depths of $0-15,15-30,30-60 \mathrm{~cm}$.

The samples were preserved in the field using methanol and stored at $4^{\circ} \mathrm{C}$ until analysis. Extraction was done using Brinkmann Buchi automated apparatus. Sample clean up was undertaken with a $6 \mathrm{~mL}$ dual layer glass Florisil ${ }^{\oplus} / \mathrm{Na}_{2} \mathrm{SO}_{4}$ SPE Tube $2 \mathrm{~g} / 2 \mathrm{~g}$. The clean-up procedure effectively removed polar hydrocarbons of natural origin, moisture, impurities, colour interferences and did not have any significant effect on the amount of petroleum hydrocarbons present. 


\subsection{Instrumentation}

GC-FID method for the determination of petroleum hydrocarbons in soil was developed based on modifications of the reported methods [12] [13] [14]. The choices of GC-FID over Photo Ionisation Detector (PID) are: 1) FID can handle very wet samples and equally cope with high humidity than PID. 2) In FID, the flame is capable of ionising large range of volatile organic and petroleum hydrocarbons than PID, thereby detecting a wide array of hydrocarbons. 3) FID is very useful in detecting lower concentrations of volatile organics because of its lower detection limits. FID limitations [14] include sample dilution, ability to detect volatile hydrocarbons from non-petroleum matter and organic material such as methane and BTEX.

The system consisted of a Varian BV, CP-3800 gas chromatograph coupled to the FID detector and equipped with an automatic sampler CTC Analytics CombiPAL and the 1177 split/splitless injector. The GC capillary (WCOT) column was a non polar, CP-Sil $8 \mathrm{CB}$ Low Bleed/MS polymer; $30 \mathrm{~m}$ long, $0.25 \mathrm{~mm}$ inside diameter (id), $0.39 \mathrm{~mm}$ outside diameter $(0 \mathrm{~d}), 0.25 \mu \mathrm{m}$ film thickness, coating of 95\% methyl, 5\% phenylpolysiloxane. The initial column temperature programmed at $30^{\circ} \mathrm{C}$ for $3 \mathrm{~min}$. to identify and separate the volatile components. The temperature was increased to $320^{\circ} \mathrm{C}$ at the rate of $8^{\circ} \mathrm{C} \mathrm{min}^{-1}$ and held for extra $15 \mathrm{~min}$. The carrier gas was helium ( $99.99 \%$ pure) at velocity of $26 \mathrm{~cm} \cdot \mathrm{sec}^{-1}$. Sample injection volume of $1 \mu \mathrm{L}, 1: 25$ split ratio and column flow rate of $1.0 \mathrm{~mL} \cdot \mathrm{min}^{-1}$ were applied. Detector (FID) and injector temperature were $320^{\circ} \mathrm{C}$ and $300^{\circ} \mathrm{C}$ respectively.

\section{Results and Discussion}

\section{Method Validation}

Identification and quantification of the samples was based on the comparison of the chromatographic data with the reference standards 1) Alkane Mix, $\mathrm{C}_{10}-\mathrm{C}_{40}$, 2) DRO, $\mathrm{C}_{10}-\mathrm{C}_{25}$ 3) BTEX (benzene, toluene, ethylbenzene and total xylene) (iv) Retention Time window-RTW, $\mathrm{C}_{10} \& \mathrm{C}_{40}$ (v) hydrocarbons $\mathrm{C}_{10}, \mathrm{C}_{11}, \mathrm{C}_{14}, \mathrm{C}_{15}$, TCD (Thermal conductivity detector) (Figures 1-4). Quantitative analysis was computed based on [18]. The average percentage recovery was $78.7 \% \pm 26 \%$. The analysis of all the samples was carried out along with the standards. Each sampling point/hole yielded three samples taken at different depths, i.e. $0-15 \mathrm{~cm}$ (top), $15-30 \mathrm{~cm}$ (middle) and $30-60 \mathrm{~cm}$ bottom).

Samples were analysed and chromatograms overlaid to confirm the identity and retention times with the reference standards. The average peak values of all the samples were recorded and their standard deviation and \% RSD calculated at 95\% confidence level.

The analysis of the solvent blank (DCM), thimble extract and control samples taken from similar geographical non-spilled areas, randomly collected and analyzed as the standards along side with other samples had no indication of trace of hydrocarbons or other contaminants since appropriate controls were carried out. 


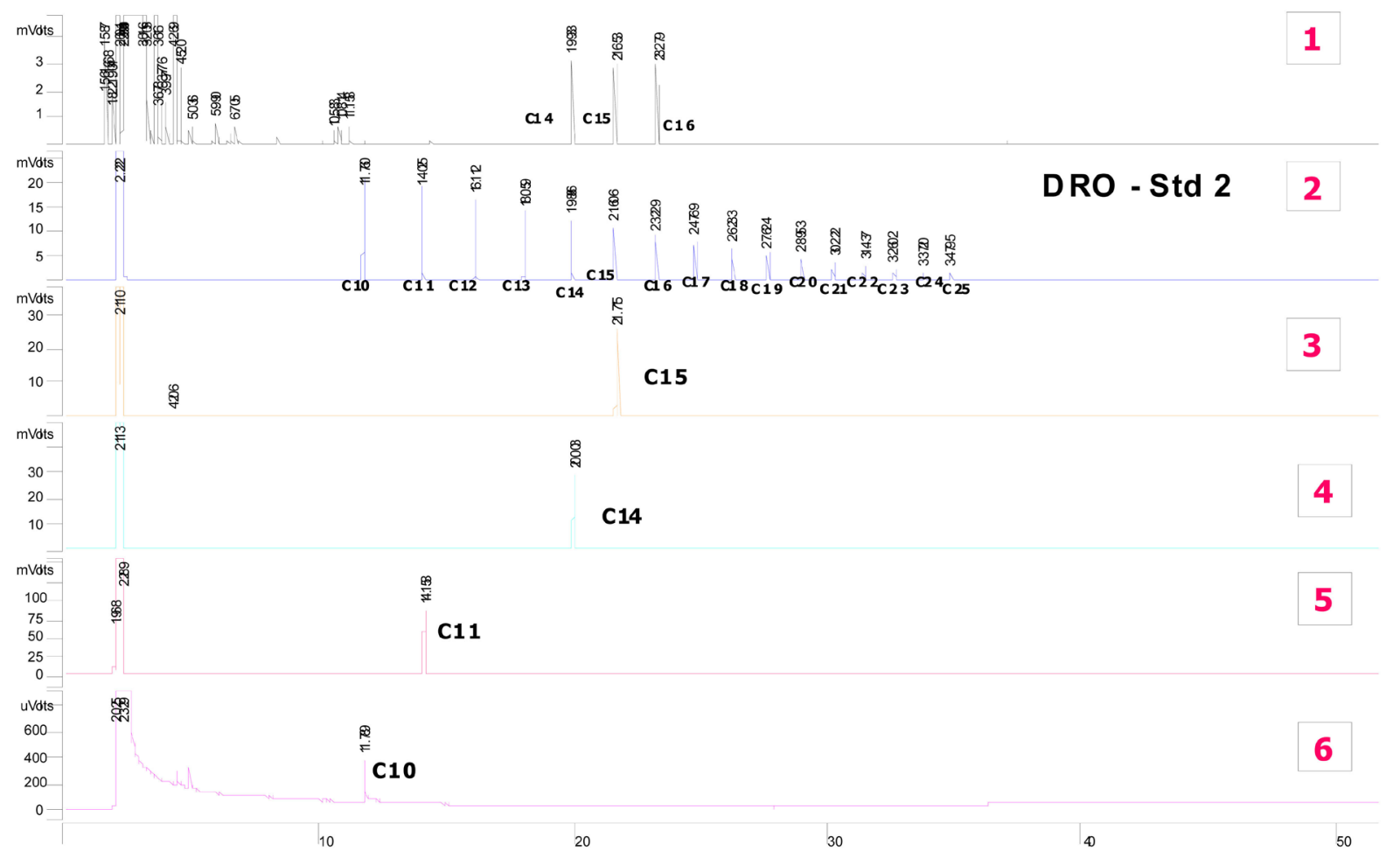

Figure 1. Laboratory standards $\left(\mathrm{C}_{10}, \mathrm{C}_{11}, \mathrm{C}_{14}\right.$, and $\left.\mathrm{C}_{15}\right)$, TCD (chromatogram 1) overlaid with the Diesel Range (Organics DRO).

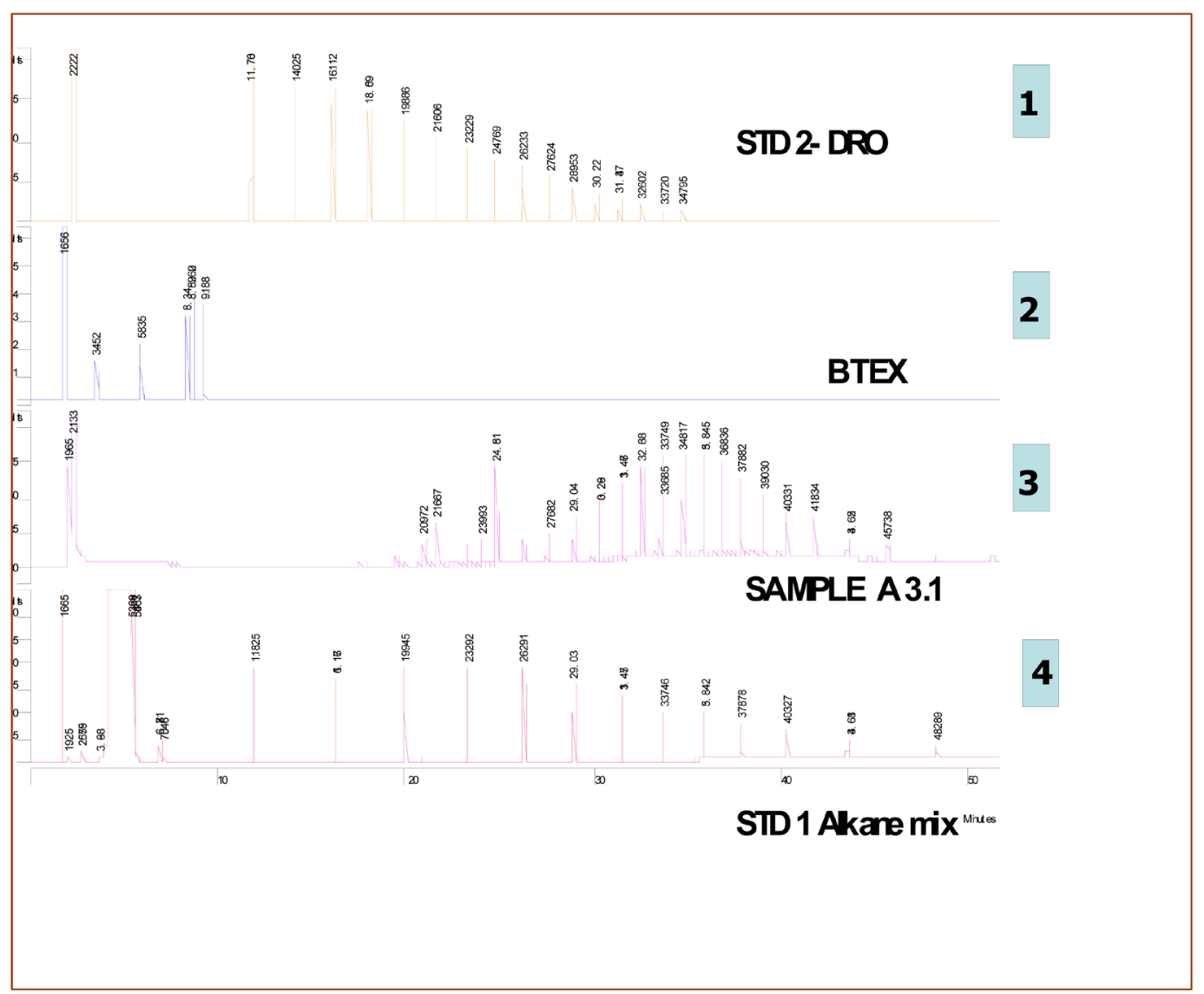

Figure 2. Chromatograms of reference standards (Alkane mix, DRO \& BTEX) and a sample No. 3 top soil (3.1). 


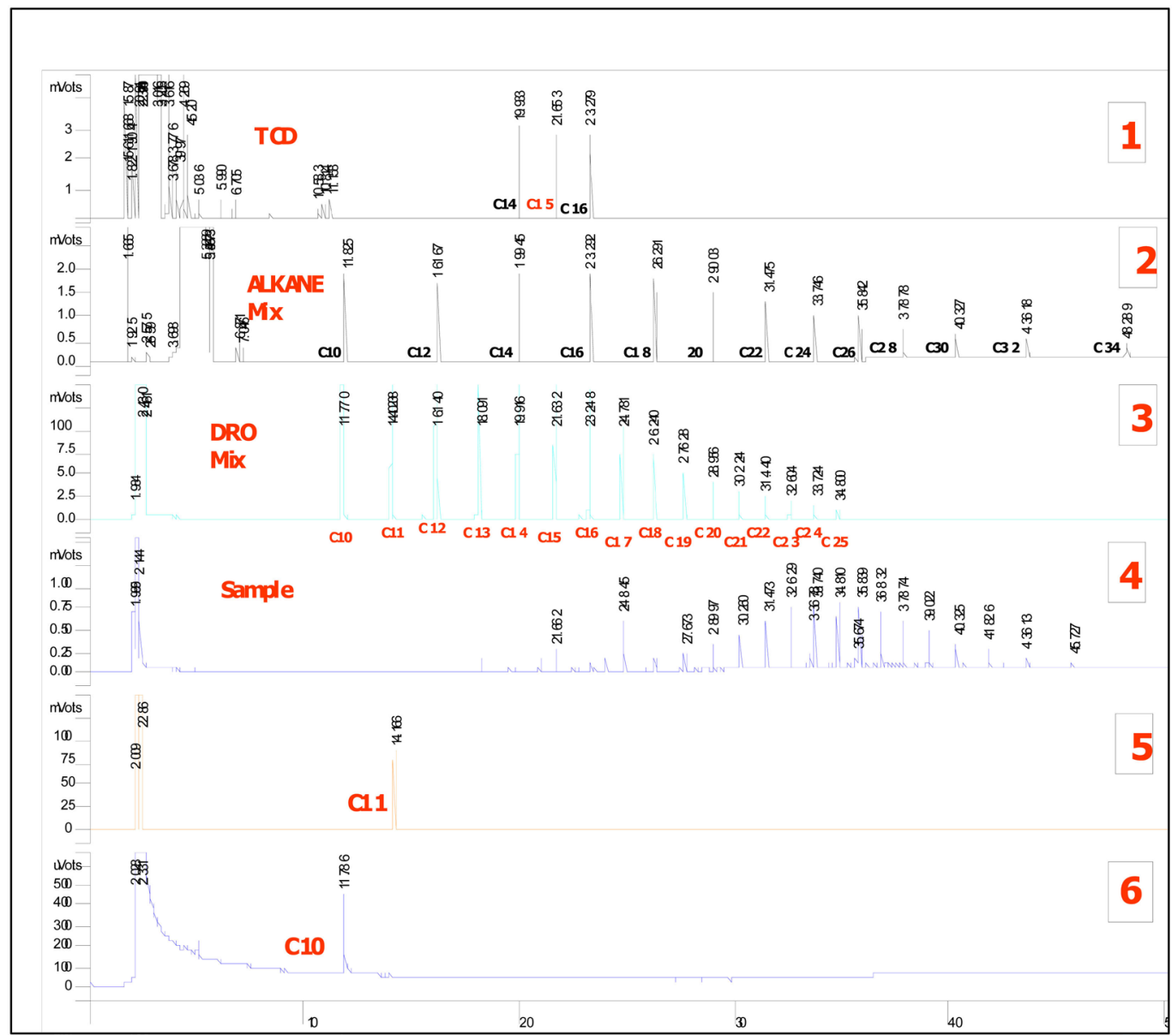

Figure 3. Sample 3.1 (chromatogram 4) was compared with the reference standards (chromatograms $2 \& 3$ ) and other lab standards (chromatograms 1, 5 and 6) for confirmation of the eluted peaks in samples.
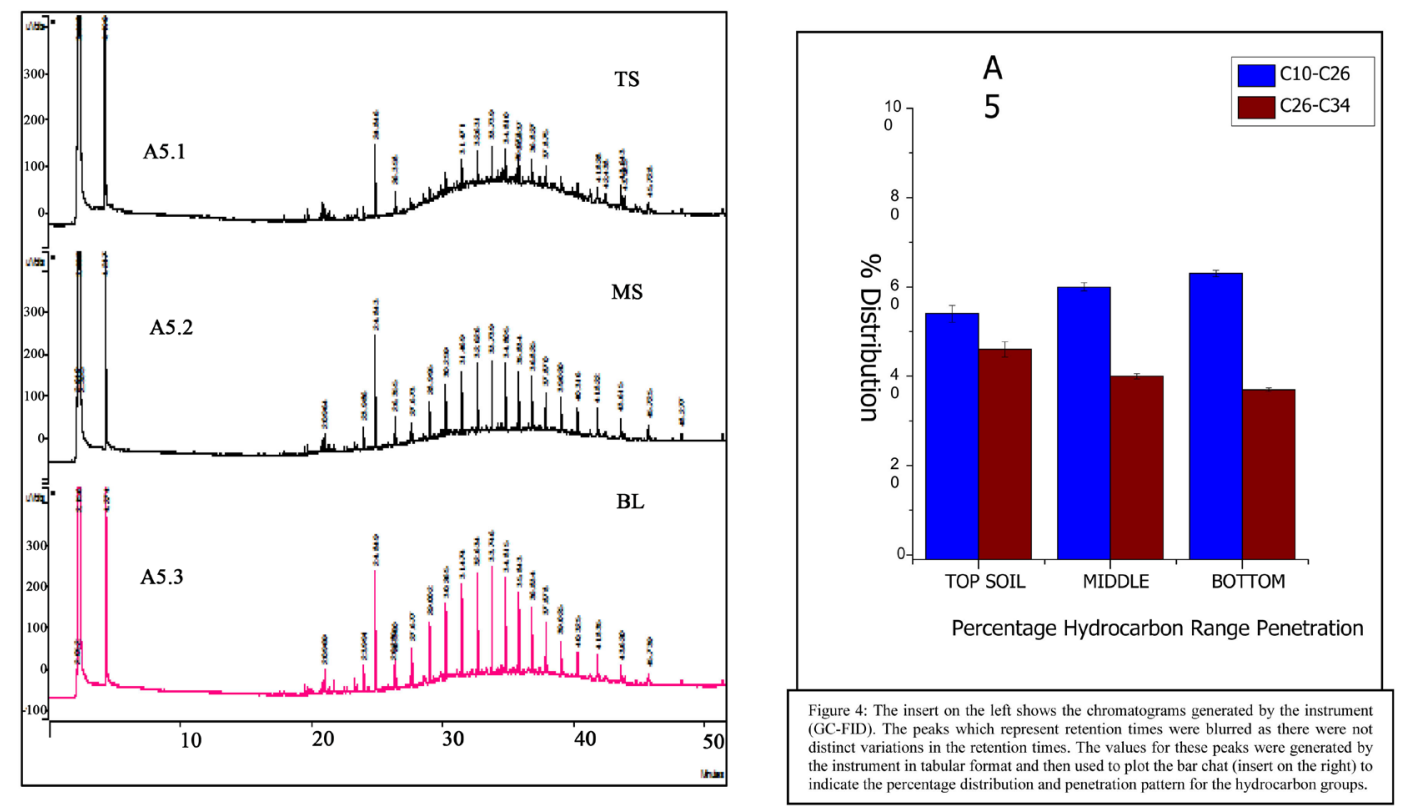

Figure 4. The chromatogram (left) with the corresponding bar graph for the distribution, migration and penetration (right) of samples in site A 1, 3, 5, 8 and site B 1 \& B3 with DRO and WOO competitively penetrating the soil levels. 
The Diesel Range Organics (DRO) reference standard was analysed along with the prepared laboratory standard to validate the eluted peaks (Figure 1).

The peaks eluted from all the five standards $\mathrm{C}_{10}, \mathrm{C}_{11}, \mathrm{C}_{14}, \mathrm{C}_{15}$ and the reference standard, DRO $\left(\mathrm{C}_{10}-\mathrm{C}_{25}\right)$ were analyzed concurrently in order to ascertain the reproducibility of the chromatographic optimization process.

The three reference standards-DRO, alkane mix and BTEX were analysed with the sample at the same time using the optimised method (Figure 2). The sample, chromatogram 3, had no trace of BTEX. The inability to elevated levels of BTEX peaks in the sample could be attributed to their solubility in soil water, atmospheric temperature, type and extent of contamination [19] and evaporation [20] of the light crude oil on exposure for sometime time before sampling and analysis.

All the petroleum contaminants in the soil that were qualitatively identified and quantitatively validated fell within $\mathrm{C}_{10}$ to $\mathrm{C}_{34}$ (Figure 3 ).

Sample number 3 (top soil-A3.1) was used to represent the other samples because it showed the widest spread of the contaminants in the optimized retention time window method with the last compound eluting at $45.73 \mathrm{~min}$. RTWs were established to compensate for the minor shifts in absolute retention times as a result of sample loadings and normal chromatographic variability.

The overall concentration of total petroleum hydrocarbon (TPH) of each sample depth at the site were established and presented in Table 3.

In Table 3, the TPH concentration for the top soils ( $15 \mathrm{~cm}$ depth) range from ( $9 \pm 7$ to $\left.289 \pm 15 \mathrm{mg} \cdot \mathrm{kg}^{-1}\right)$. The mid or sub-soils ( $30 \mathrm{~cm}$ depth) had a concentration range of $(8 \pm 1$ to $318 \pm 4) \mathrm{mg} \cdot \mathrm{kg}^{-1}$ and a range of $\left(7 \pm 1\right.$ to $\left.163 \pm 15 \mathrm{mg} \cdot \mathrm{kg}^{-1}\right)$ was recorded for the $60 \mathrm{~cm}$ depths measured. The overall level of TPH recorded here in the petroleum contaminated site ranged from $\left(7 \pm\right.$ to $\left.318 \pm 4 \mathrm{mg} \cdot \mathrm{kg}^{-1}\right)$. Sample No.3 in site B had the highest TPH concentration $\left(314 \pm 4 \mathrm{mg} \cdot \mathrm{kg}^{-1}\right)$ in the mid soil $(15-30 \mathrm{~cm})$ depth followed by $294 \pm 16 \mathrm{mg} \cdot \mathrm{kg}^{-1}$ for the top soil of sample No. 3 in site A.

The greatest depths measured $(60 \mathrm{~cm})$ in most of the samples recorded had significantly low value of TPH though concentrations of total petroleum hydrocarbons did not decrease generally with depth.

The concentration of TPH at the mid/sub-soil $(15-30 \mathrm{~cm})$ depth was higher than the concentration range reported by [21] [22] [23] for oil spilled soils of other parts of Niger Delta. However, no significant level of TPH was recorded for the control soil samples taken from similar geographical non-spilled areas. The samples showed elevated concentration of TPHs when compared with control samples in all the sites. The high levels of TPH contamination observed in this study for spilled soils far exceeded the fifty parts per million $\left(50 \mathrm{mg} \cdot \mathrm{kg}^{-1}\right.$ or ppm) compliance baseline limit [24] set for petroleum industries in Nigeria.

High concentration levels of hydrocarbons present in contaminated sites could pose a health risk to humans, plants and animal lives. Assessment of the penetration capability of the hydrocarbon contaminants were carried out. It became imperative to assess the type of hydrocarbons and the extent of depth 
Table 3. A summary of average total hydrocarbon content $\left(\mathrm{mg} \cdot \mathrm{kg}^{-1}\right)$ in the samples and the controls.

\begin{tabular}{|c|c|c|c|c|c|c|c|c|c|c|}
\hline & \multirow{2}{*}{ No. } & \multicolumn{3}{|c|}{ Sample Mass (g) } & \multicolumn{3}{|c|}{$\begin{array}{c}{ }^{*} \text { Average Peak } \\
\left.\text { Area } \mathrm{mV}^{-\mathrm{sec}}\right)\end{array}$} & \multicolumn{3}{|c|}{$\begin{array}{l}\text { Hydrocarbon Content } \\
\left(\mathrm{mg} \cdot \mathrm{kg}^{-1}\right) \text { or }(\mathrm{ppm})\end{array}$} \\
\hline & & TS & MS & $\mathrm{BL}$ & TS & MS & $\mathrm{BL}$ & TS & MS & $\mathrm{BL}$ \\
\hline \multicolumn{11}{|l|}{ SITE A } \\
\hline 1 & 3 & 10.16 & 10.00 & 10.06 & 546 & 889 & 439 & $94 \pm 25$ & $156 \pm 26$ & $76 \pm 39$ \\
\hline 2 & 2 & 10.49 & 10.25 & $* *$ & 797 & 388 & ** & $133 \pm 38$ & $66 \pm 19$ & ** \\
\hline 3 & 3 & 10.00 & 10.10 & 10.00 & 1343 & 1697 & 933 & $235 \pm 5$ & $294 \pm 16$ & $163 \pm 15$ \\
\hline 4 & 3 & 10.01 & 10.11 & 10.02 & 443 & 482 & 482 & $77 \pm 44$ & $84 \pm 18$ & $84 \pm 14$ \\
\hline 5 & 3 & 10.10 & 10.30 & 10.00 & 605 & 515 & 560 & $105 \pm 11$ & $88 \pm 4$ & $98 \pm 3$ \\
\hline 6 & 3 & 10.08 & 10.00 & 10.00 & 54 & 48 & 45 & $9 \pm 7$ & $8 \pm 1$ & $7 \pm 1$ \\
\hline 7 & 3 & 10.00 & 10.02 & 10.01 & 45 & 51 & 46 & $10 \pm 2$ & $9 \pm 1$ & $8 \pm 2$ \\
\hline 8 & 3 & 10.02 & 10.39 & 10.48 & 259 & 323 & 345 & $45 \pm 11$ & $54 \pm 7$ & $58 \pm 13$ \\
\hline \multicolumn{11}{|l|}{ SITE B } \\
\hline 1 & 3 & 10.13 & 10.10 & NA & 248 & 216 & NA & $43 \pm 18$ & $37 \pm 6$ & NA \\
\hline 2 & 3 & 10.01 & 10.02 & NA & 269 & 202 & NA & $47 \pm 10$ & $34 \pm 7$ & NA \\
\hline 3 & 3 & 10.08 & 10.02 & NA & 1668 & 1820 & NA & $289 \pm 15$ & $318 \pm 4$ & NA \\
\hline 4 & 3 & 10.00 & 10.00 & 10.14 & 283 & 216 & 287 & $50 \pm 13$ & $38 \pm 4$ & $49 \pm 3$ \\
\hline \multicolumn{11}{|l|}{$\begin{array}{l}\text { Control } \\
\text { samples }\end{array}$} \\
\hline 1 & 3 & 10.11 & 10.02 & 10.10 & 0.0 & 0.0 & 0.0 & 0.0 & 0.0 & 0.0 \\
\hline 2 & 3 & 10.01 & 10.11 & 10.00 & 0.0 & 0.0 & 0.0 & 0.0 & 0.0 & 0.0 \\
\hline 3 & 3 & 10.20 & 10.14 & 10.11 & 0.0 & 0.0 & 0.0 & 0.0 & 0.0 & 0.0 \\
\hline 4 & 3 & 10.00 & 10.12 & 10.13 & 0.0 & 0.0 & 0.0 & 0.0 & 0.0 & 0.0 \\
\hline TOTAL & 47 & & & & & & & & & \\
\hline
\end{tabular}

TS = Top soil; MS = Mid soil; BL = Bottom level. ${ }^{*}$ Not sampled due to impervious rock obstruction.

penetration for the purpose of remediation and record. This section of investigation classified the hydrocarbons into groups based on their degree of penetration within the soil strata. Basically, three major groups of petroleum hydrocarbons are known, classified and adopted in this work. These are: 1) The Gasoline Range Organics (GRO), generally eluting in window $\mathrm{C}_{5}-\mathrm{C}_{9}$. 2) The Diesel Range Organics (DRO) elutes from $\mathrm{C}_{10}-\mathrm{C}_{26}$. 3) The Waste Oil Organics (WOO), eluting above $\mathrm{C}_{26}$. The presence and concentrations of $\mathrm{C}_{10}-\mathrm{C}_{26}, \mathrm{C}_{26}$ and above had been identified and quantified. The penetration, percentage distribution and migration of these groups of hydrocarbons in the samples were considered.

However, for the purpose of this assessment, the site samples were classified into three fundamental groups based on the observed pattern of the hydrocarbon penetration and distribution.

Group 1 pattern was exhibited by six (6) samples (A1, A3, A5, A8, B1 \& B3), 
each comprising of three (3) sampling depths. This group had both DRO $\left(\mathrm{C}_{10}-\mathrm{C}_{26}\right)$ and WOO $\left(\mathrm{C}_{26}\right.$ and above $)$ with competitive penetration capacity as represented in Figure 4 with DRO having much penetration concentration.

Group 2 has three (3) samples (A6, A9 and B4) exhibiting similar spatial penetration and distribution pattern. In this group, $100 \%$ presence of DRO was found in all the soil depths with no contribution from WOO (Figure 5).

There are 3 samples (A2, A4 \& A7) making group 3, in which DRO dominates the soil depths with little contribution from the Lubricating or waste oil hydrocarbon (WOO) range- $\mathrm{C}_{26} \&$ above (Figure 6).

In the graphical representations in Figures 4-6, each sample shows three different depths of $15 \mathrm{~cm}$ (TS), $30 \mathrm{~cm}$ (MS) and $60 \mathrm{~cm}$ (BL). The chromatogram for each sample is represented with a bar graph side by side showing penetration and distribution of hydrocarbons in the range $\mathrm{C}_{10}-\mathrm{C}_{20}$ and $\mathrm{C}_{21}-\mathrm{C}_{34}$ through the measured soil levels.

Figure 4 showed the penetration pattern for the samples listed as exemplified by sample number 5 in site A (A5). Both DRO and WOO present in the samples penetrated the soil competitively. In the top soil level (TS) the percentage distribution of these contaminants are: DRO (52\%) \& WOO (48\%). Mid soil (MS) has $60 \% \mathrm{DRO}$ and $40 \% \mathrm{WOO}$ and the $60 \mathrm{~cm}$ level (BL) measured, had $62 \%$ and $32 \%$ of DRO and WOO respectively.

Samples illustrated in Figure 5 indicated 100\% selective penetration and distribution of DRO contaminants. The penetration pattern is crucial as only DRO were detected. WOO contaminants were not found at all levels of soil under test.
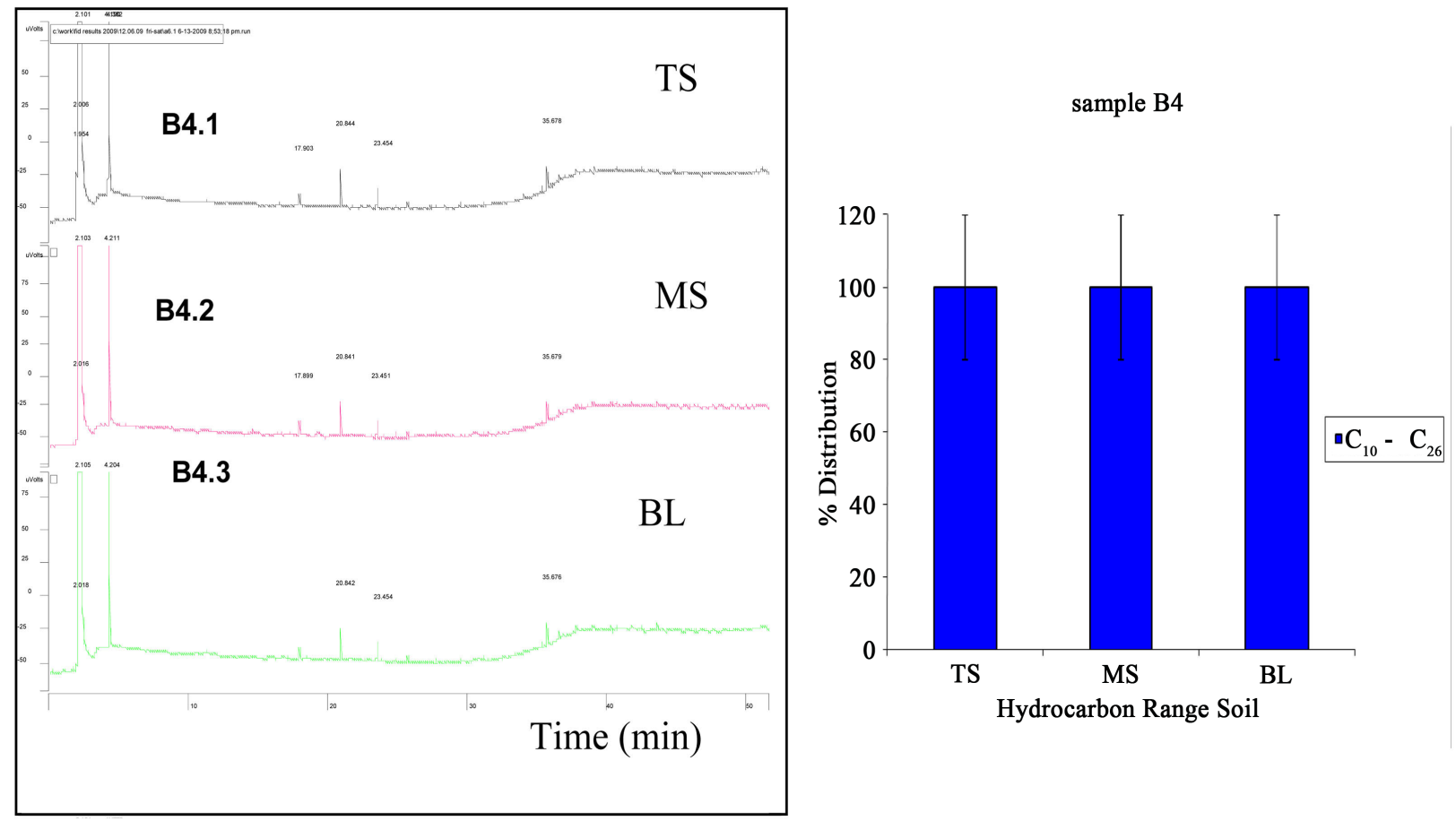

Figure 5. DRO contaminants had $100 \%$ migration and penetration competence in the top soil (TS), mid soil (MS) and the bottom level (BL) of the three samples (A6, A9 \& B4). 

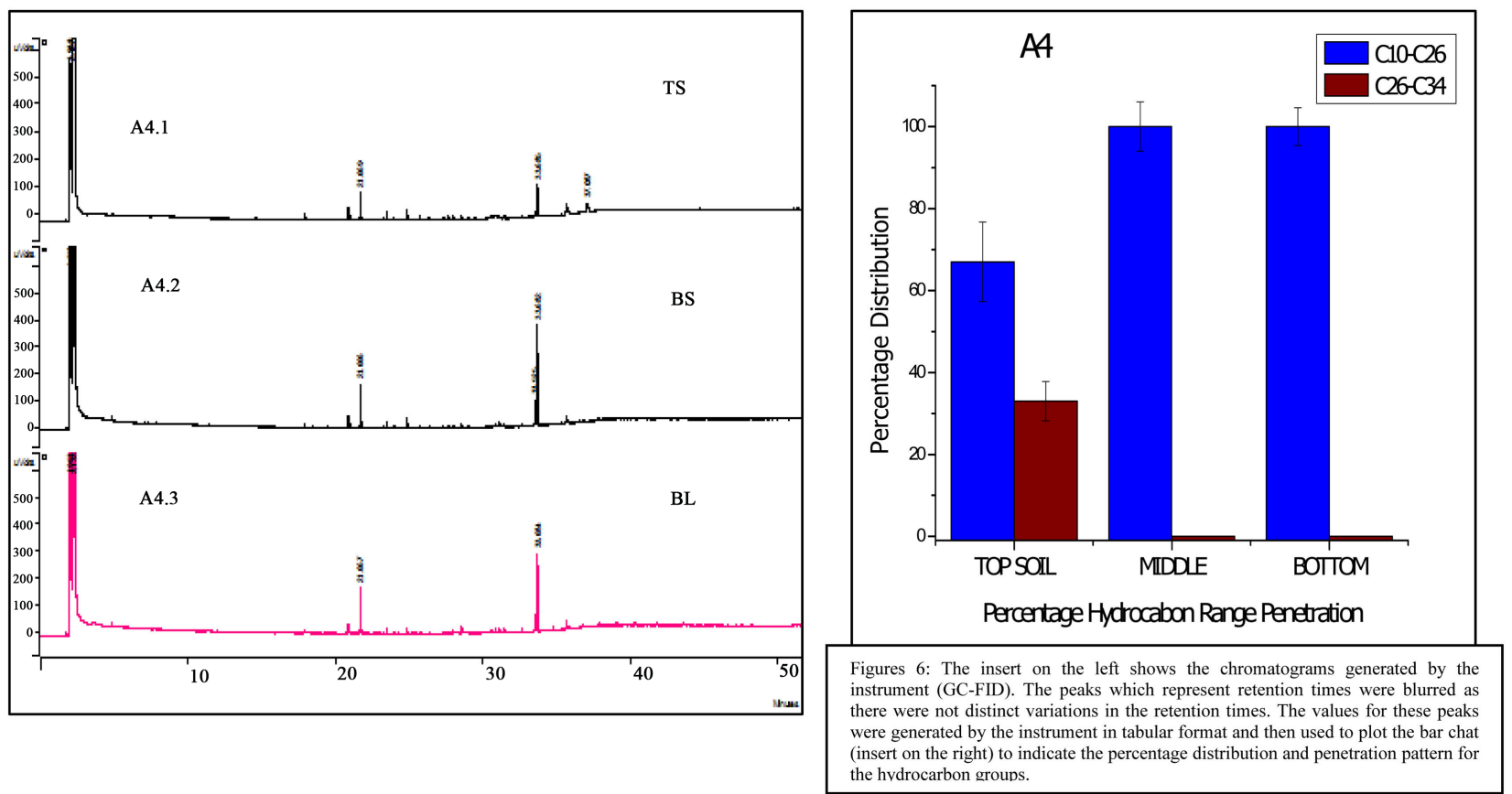

Figure 6. Samples in site A1, A4, \& A7 had the same distribution and penetration pattern with significant presence of DRO $\left(\mathrm{C}_{10}-\mathrm{C}_{26}\right)$ in almost all the levels measured.

Soil sample A4 in Figure 6 showed $66 \%$ of DRO in the top soil and $100 \%$ in both the mid and lest depth of soil measured. WOO had $34 \%$ presence in the TS and was significantly not detected at the mid soil and last level measured.

BTEX range of volatile organics were not detected in this analysis partly due to its reduced concentration resulting from evaporation after prolonged exposure of the spill before sampling was undertaken.

\section{Conclusions}

A method for the analysis of soils spilled with crude oil was developed and optimized. The results in this study revealed that the TPH concentration in the all the levels of soil strata measured ranged from $7 \pm 1$ to $318 \pm 4 \mathrm{mg} \cdot \mathrm{kg}^{-1}$. The concentrations and penetration ranges for two groups of TPHs $-\mathrm{C}_{10}-\mathrm{C}_{26}$ (Diesel Range Organics) and $\mathrm{C}_{26}-\mathrm{C}_{34}$ (Waste Oil Organics) were recognised.

Despite limited information on the migration and depth penetration of hydrocarbons in soils, data from this study showed the types, distribution, migration and penetration capability of the petroleum hydrocarbon contaminants in the study area.

The spatial distribution and penetration pattern of petroleum contaminants at the investigated site were established as an informative guide to the Government and oil industries during remediation process.

\section{Conflicts of Interest}

The authors declare no conflicts of interest regarding the publication of this paper. 


\section{References}

[1] Chukwujindu, M.A., Iwegbue, E.S. and Nwajei, G.E. (2008) Characteristic Levels of Total Petroleum Hydrocarbon in Soil Profile of Automobile Mechanic Waste Dumps. International Journal of Soil Science, 3, 48-51. https://doi.org/10.3923/ijss.2008.48.51

[2] Bosco, M.L., Varrica, D. and Dongarra, G. (2005) Case Study: Inorganic Pollutants Associated with Particulate Matter from an Area Near a Petrochemical Plant. Environmental Research, 99, 18-30. https://doi.org/10.1016/j.envres.2004.09.011

[3] Guidance for Remediation of Petroleum Contaminated Sites Toxics Cleanup Program Washington State Department of Ecology Olympia (2016) Washington Publication No. 10-09-057.

[4] Edwin-Wosu, N.L. and Albert, E. (2010) Total Petroleum Hydrocarbon Content (TPH) as an Index Assessment of Macrophytic Remediation Process of a Crude Oil Contaminated Soil Environment. Journal of Applied Sciences and Environmental, 14, 39-42. https://doi.org/10.4314/jasem.v14i1.56486

[5] Freitag, D., Ballhorn, L., Geyer, H. and Korte, F. (1985) Environmental Hazard Profile of Organic Chemicals: An Experimental Method for the Assessment of the Behaviour of Organic Chemicals in the Ecosphere by Means of Simple Laboratory Tests with 14C Labelled Chemicals. Chemosphere, 14, 1589-1616. https://doi.org/10.1016/0045-6535(85)90014-1

[6] Department of Environmental Conservation (DEC) (1992) Petroleum-Contaminated Soil Guidance Policy. Spills Technology and Related Series (STARS). New York.

[7] Torres, L.G., Aguirre, A.L., Verdejo, A. and Iturbe, R. (2005) Sampling of Water, Soil and Sediment to Trace Organic Pollutants. Analytical and Bioanalytical Chemistry, 81, 541-550.

[8] New York State (NYS) for Environmental Conservation, Cleanup Standard Task Force (1991) Cleanup Policy and Guidelines.

[9] Department of Environmental Conservation (1992) Petroleum-Contaminated Soil Guidance Policy. Remediation Guidance Document. New York.

[10] Alain, H., Silvia, L. and Damiá, B. (2006) Sampling of Water, Soil and Sediment to Trace Organic Pollutants. Analytical and Bioanalytical Chemistry, 386, 1075-1088. https://doi.org/10.1007/s00216-006-0486-2

[11] Tadeusz, G. and Jacek, N. (2002) Passive Sampling. Trends in Analytical Chemistry, 21, 276-291. https://doi.org/10.1016/S0165-9936(02)00407-7

[12] Environmental Agency (2003) Principles for Evaluating the Human Health Risks from Petroleum Hydrocarbons in Soils. A Consultation Paper. R \& D Technical Report P5-080/TRI. P 10.

[13] Annual Book of ASTM Standards (2005) Soil Investigation and Sampling by Auger Borings, Practice for D 1452. 125-126.

[14] US EPA Method 3540C Soxhlet Extraction (1996).

[15] Annual Book of ASTM Standards (2005) Extraction of Solid Waste Samples for Chemical Analysis Using Soxhlet Extraction, Environmental Assessment, Hazardous Substances and Oil Spill Responses, Practice for D 5369. 196-201.

[16] Draft International Standard ISO/DIS 13877 (1995).

[17] Berst, J.D., Ejem, M., Holzer, R. and Lischer, P. (1999) Comparison of Different Drying, Extraction and Detection Techniques for the Determination of Priority Polycyclic Aromatic Hydrocarbons in Background Contaminated Soil Samples. 
Analytica Chimica Acta, 383, 263-275.

https://doi.org/10.1016/S0003-2670(98)00817-4

[18] USEPA (2007) New Test Methods 8000C for Determinative Chromatographic Separations. Industrial Research, 50, 247-250.

[19] Hokstad, J.N., Faksness, L.G. and Daling, P.S. (2000) SPE Paper 61468. International Conference on Health, Safety, and the Environment in Oil \& Gas Exploration \& Production, Stavanger, 26-28 June 2000.

[20] Mohammed, M.A. (2004) Treatment Techniques of Oil-Contaminated Soil and Water Aquifers. International Conference on Water Resources and Arid Environment, Gaborone, 3-6 August 2004, P2.

[21] Iwegbue, C.A., Nwajei, G.E. and Arimoro, F.O. (2007) Pakistan Journal of Scientific and Industrial Research, 50, 247-250.

[22] Ekudanyo, E.O and Obuekwe, O.O. (2004) Environmental Monitoring and Assessment. Springer, Berlin.

[23] Adeniyi, A.A. and Afolabi, J.A. (2002) Determination of Total Petroleum Hydrocarbons and Heavy Metals in Soils within the Vicinity of Facilities Handling Refined Petroleum Products in Lagos Metropolis. Environment International, 28, 79-82. https://doi.org/10.1016/S0160-4120(02)00007-7

[24] DPR (1991) Environmental Guidelines and Standards for the Petroleum Industry in Nigeria. Department of Petroleum Resources, Ministry of Petroleum and Mineral Resources, Lagos. 